\title{
Biofuel Production Using Marine Microbes
}

\author{
Kalaiselvi V. and Jayalakshmi S.* \\ Centre of Advanced Study in Marine Biology, Annamalai University, India \\ *jayacas@gmail.com
}

\begin{abstract}
One of the greatest challenges for world in the twenty-first century is to meet the growing demand for energy for transportation, heating and industrial processes and to provide raw material for the industry in a sustainable way. Today, ethanol is being promoted as a clean and renewable fuel that will reduce global warming, air pollution and reliance on diminishing gasoline. In the present study conversion of agricultural residue such as wood powder, corn stalk, paddy straw, ragi stalk, millet stalk and sugarcane stalk in to ethanol production was aimed by two processes. 1 . Hydrolysis of cellulosed in lignocellulosic materials to fermentable reducing sugars using cellulolytic marine bacteria and 2 . Fermentation of the sugars to ethanol using marine yeast. Among the 15 potential cellulase producers isolated, 3 strains namely Klebsiella ozeanae, Pseudomonas aerugionsa and Enterobacter cloacae were found to be the most potent strains. Growth optimization study revealed that K. ozeanae preferred $\mathrm{pH}$ : 7 , temperature: $35^{\circ} \mathrm{C}$, salinity: $3 \%$ and 30 hours of incubation period as optimum for maximum growth. Whereas for $P$. aeruginosa the optimum growth conditions were $\mathrm{pH}: 8$, temperature: $35^{\circ} \mathrm{C}$, Salinity: $2 \%$ and 36 hours incubation period. Likewise for E. cloacae it was $\mathrm{pH}: 7$, temperature: $35^{\circ} \mathrm{C}$, Salinity: $2 \%$ and 36 hours incubation period. All the strains preferred cellulose as the most preferable substrate for the cellulase production at which 271, 263 and $231 \mathrm{U} / \mathrm{ml} / \mathrm{min}$. of enzyme activity was observed for $K$. ozeanae, $P$. arurginosa and $E$. cloacae respectively. Among the nitrogen sources yeast extract showed maximum enzyme activity in the above strains respectively of 282, 275 and $263 \mathrm{U} / \mathrm{ml} / \mathrm{min}$. in mass scale production with $1 \%$ cellulose as carbon source and $1 \%$ yeast extract as nitrogen source resulted in 293, 280 and $264 \mathrm{U} / \mathrm{ml} / \mathrm{min}$. enzyme activity was observer for $K$. ozeanae, $P$. aeruginosa and $E$. cloacae respectively. It was interesting to note that with cheaper substrate (wood powder) also almost equal amount of enzyme production was observed. When all three strains were used as a consortium at optimum growth conditions such as $\mathrm{pH}-7$, temperature- $35^{\circ} \mathrm{C}$, salinity $-2 \%, 30$ hrs incubation period in an anaerobic condition $11 \%$ of ethanol production was observed which was found to be highest ever reported. These wild strains as such cane be used for industrial ethanol production.
\end{abstract}

Keywords: Microbs, biofuel, Hydrolysis, Fermentation

Proceedings of the International Forestry and Environment Symposium 2016, Department of Forestry and Environmental Science, University of Sri Jayewardenepura, Sri Lanka. 